\title{
Review Article The Indian Graphic Novel: Nation, History and Critique
}

\author{
Pramod K. Nayar, The Indian Graphic Novel: Nation, History and Critique (Routledge, First \\ South Asia Edition, 2016), 212 Pages, 895 Rupees, ISBN 978-1-138-66851-5. \\ Reviewed by Rajni Singh \\ Associate Professor, Indian Institute of Technology (Indian School of Mines), Dhanbad, \\ India. ORCID: oooo-0oo2-1569-8339. Email: rajnisingh18@gmail.com
}

In this deftly constructed study, Pramod K. Nayar's orientation is towards engendering an acceptance for the Indian graphic novel which is still fairly new to the connoisseurs, scholars and students of Indian Writing in English. Through an investigative and analytical approach he looks at the Indian graphic novel that possesses all the requisites of a literary text. Talking about the form of the graphic narrative, he argues that it has an edge over the other dominant genres as it simultaneously engages the reader to the act of reading and perceiving and that its form is enriched with range and versatility. It embodies a unique interplay of word and image, the literal and the symbolic layer of interpretation and even its gaps or absences render a field of signification. It not only communicates with its readers, but directly involves them and makes them the key players in the production of meaning. Its 'seeable' and 'sayable' mode allows the reader to inhabit the virtual space. Embedded with the power of the visual-the verbal-the gaps, the graphic narratives have

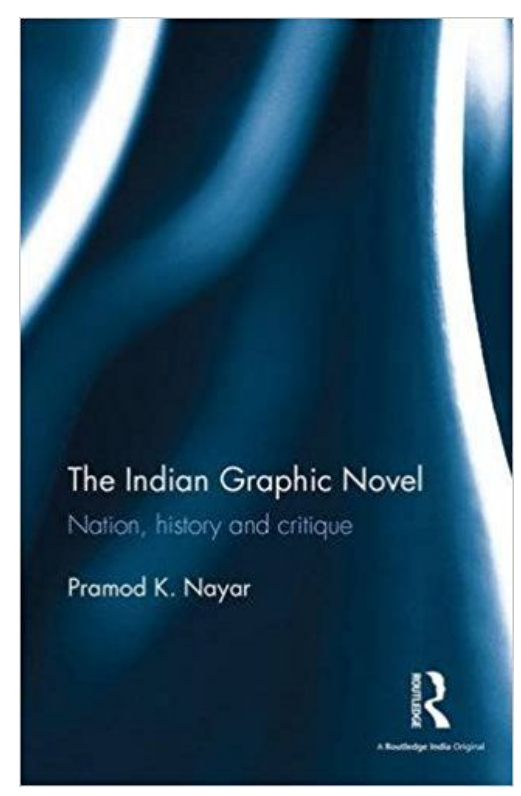
become a potent medium to satirize and critique upon the follies of the society. Pondering over the appropriate form in which to represent or examine the issues of the nation, Nayar finds the medium to be the most befitting one. He vehemently asserts that the Indian graphic novel is perhaps the new literary form that the nation has been 'longing for'. He contends, "For this freedom of representation, for taking the process of critique into a medium associated with just entertainment, for its opening up an array of story-telling strategies and for its insistence on tackling more social commentary and cultural critique of the nation's lacunae of flaws, the graphic novel heralds a major shift within IWE." (p. 8) Nayar's claim is undisputed, but one cannot brush aside the fact that the Indian graphic narrative's move from margin to mainstream may perhaps not be so easy in an academic culture where there is limited scope for experimentation and inclusion of the 'new'. Also this form has to rigorously compete with the dominant literary forms of IWE. Undoubtedly in the West, the graphic novel has witnessed a spectacular rise which has put an end to the debate on its legitimacy and the credit to its renewed status goes to the several promotional platforms such as publishing houses, literary magazines, journals, university classrooms that have been instrumental in establishing it as a work of

(c) AesthetixMS 2016. This Open Access article is published under a Creative Commons Attribution Non-Commercial 4.0 International License (http://creativecommons.org/licenses/by-nc/4.o/), which permits non-commercial re-use, distribution, and reproduction in any medium, provided the original work is properly cited. For citation use the DOI. For commercial re-use, please contact editor@rupkatha.com. 
seriousness and merit. Nayar, too, attempts to situate the Indian graphic novel as a work of scholarship. He engages with the history of graphic text for an understanding of the medium.

The study opens with the definitional problems in 'comics', 'graphic novels', and 'graphic narratives', which are addressed through a range of references made to critic-practitioners like Scott McCloud, Marianne Hirsch, Art Spiegelman, Thomas Doherty, Frank Miller, Rocco Versaci, Hillary Chute, Ben Lander and others.

In order to dispel the myth that surrounds the visual narrative genre - as something which is aesthetically inferior to other literary forms, a non-academic, non-serious stuff- Nayar examines the Indian graphic novel which tends to demonstrate the lives of the Indians through effective narrative and visual conventions. He analyzes the works of writers and illustrators like Orijit Sen, Sarnath Banerjee, Appupen, Viswajyoti Ghosh, Amruta Patil, Gautam Bhatia, Srividya Natarajan and S. Anand, Nina Sabnani, Pratheek Thomas and others as their texts have debated history, historical events, documented and satirized contemporary Indian culture and society.

To dwell on historical representation and its associated problems, Nayar selects stories from a transnational range of graphic narratives in which history is accessed through the verbal and the visual layers. The stories deal with ordinary people and undocumented facts without any scrupulous accuracy to provide the readers applied knowledge of the past. Instead of the 'saying' (as in history) or the 'showing' (as in historical novels) ${ }^{\mathrm{i}}$, it combines both and thus offers to its reader multiplicity of reality. The silent actors in the Graphic novel (as found in The Barn Owl's Wondrous Capers), the silences between the images, fragmented actions and movements, the kaleidoscopic arrangement of images, the deployment of space and spatial arrangements, the page layout created through gutters and frames, agency of looking, shape of panels, eye-catching posters, poster-panels with pronouncements (as in Delhi Calm) exhibit a semiotic strategy that go together in decoding the text. Nayar asserts that the visual of the graphic fiction is much effective than photography which is "memory-storing activity"ii. Photographs are 'emplotment', they capture "the public memory", but the graphic novels are "personal recall and sentimental narratives" (p. 22). In Ankur Ahuja's The Red Ledger (This Side, That Side) he demonstrates how photographs are the artefacts that ensure a post-memory. Photography "actually blocks memory, quickly becomes a counter-memory "iii. Nayar says "Expressionist language such as that of the graphic medium thus visualizes for us the exact locus of a historical moment: the human face." (p.46) and in doing so, history in graphic narrative gets repoliticised.” (p. 46)

P.K. Nayar draws our attention to the Urban Graphics and 'psychogeography'. He examines the spaces of horror in The Harappa Files and Corridor (The Barn Owl's Wondrous Capers), and spaces of desire and gynecological gothic in Kari. He states: "the subtexts of these narratives generate a critical literacy about the reality behind a confident urban India."(p. 77) He further analyzes the way the markers of cultural identity operate in graphic narratives and how 'Parergons', the seemingly unimportant or extraneous, also convey. He emphasizes on tracing the graphic voice by reading the distinctive connotations hidden beneath the theme and structure. In Sarnath Banerjee the cultural markers are woven in the form of 'tableaux' (the 'IIT' marker). He praises him for his deployment of 'Stereoscopy' for cultural commentary. Nayar avers that the visual stereoscopy "forces us to see these inequalities, fissures and oddities of Indian middle-class lives, normative femininity and state terror."(p. 102) Further, Nayar illustrates the graphic narratives' propensity for alternate histories. He sees a subtle projection of history and irony in Orijit Sen. His analysis of Srividya Natarajan's A Gardener in the Wasteland brings to the fore the other bodies in history which are presented in grotesque shapes. He suggests that these "new visual protocol(s)" compels us to "reevaluate history...to see such figures as agents of a different 
history of India as well, one of violence, discrimination and exploitation." (p. 121) Focusing on the satire in the Indian graphic novels, Nayar says that it primarily comes through 'Caricature' and 'Cartoon' along with the other modes like 'Graphic Contrasts' (juxtaposition of Alibaba and Mishra in Gautam Bhatia's Lie); 'Graphic Commentary' (the 5 different Panels on a single page that ridicule a politician's socio-political consciousness); 'Graphic Contradictions' (as presented in Sarnath Banerjee's Rakhaldas Banerjee's Plot (The Harappa Files) and Gautam Bhatia's Lie); 'Destruction of Personae' (as showcased in Vishwajyoti Ghosh's portrait of Indira Gandhi- cast as 'Moon' in Delhi Calm); 'Grotesque'; 'Exaggeration' (Banerjee’s Hydra), and 'Revelation'.

Nayar argues, "It is essential to see popular forms and their demotic registers as enabling the culturalization of the public sphere, opening it up to concerns, debates and campaigns about rights, historical wrongs and emancipator possibilities." (p. 198) Certainly the Indian graphic novel demands a critical literacy and "is poised to become a part of the global popular, taking specific local contexts and conditions of casteism or abuse via a globally hypervisible and widely recognized medium, onto the world readership screens." (p. 197)

In a highly engaging mode the study artfully moves back and forth between the theme and form, drawing the possibilities that the Indian graphic novel offers. Written in a lucid and accessible style, The Indian Graphic Novel allows its readers easy grasp of the grammar of the subject. The pleasure of reading this text is further enhanced by the illustrations, which are truly eye-catching. The book is a significant research document, interesting and absorbing, and I believe, it will enable the Indian Graphic Novel to hold a firm footing in Indian Writing in English and also help it in making its way to Indian university classrooms in the near future.

\section{Notes}

${ }^{\mathrm{i}}$ Ankersmit, Frank (2010). "Truth in History and Literature”, Narrative, Vol. 18, No. 1, Ohio State University Press, p. 45. Accessed 16-02-2017.<https://www.jstor.org/stable/pdf/25609383>

ii Haverkamp, Anselm (1993). "The Memory of Pictures: Roland Barthes and Augustine on Photography" Comparative Literature, Vol. 45, No. 3, Duke University Press, p. 258. Accessed: 16-02-2017. $<$ http://www.jstor.org/stable/1771504>

iii Barthes, Roland (200o). Camera Lucida. Trans. Richard Howard. 1980. Great Britain: Vintage. Print, 91.

Rajni Singh is Associate Professor of English, Department of Humanities and Social Sciences, IIT (ISM), Dhanbad.at IIT (ISM), Dhanbad, India. ORCID: http://orchid.org/oooo-ooo2-1569-8339. Email: rajnisingh18@gmail.com. 